\title{
Precise dating of the Norfolk timber circle
}

\author{
This curious monument on the English coast has survived for more than four millennia.
}

n August 1998, the site of a subcircular ring of 55 oak timbers surrounding a large inverted oak tree was discovered within the intertidal zone at Holme-nextthe-Sea, Norfolk $\left(52.58^{\circ} \mathrm{N}, 00.33^{\circ} \mathrm{E}\right)$. The circle, the first surviving example discovered in Britain, was in serious danger of destruction by tidal erosion, so it was imperative that detailed archaeological investigations be undertaken, including dating. Information provided by tree-ring analysis and radiocarbon measurements was combined using a bayesian approach ${ }^{1}$, resulting in a precise absolute dating for the structure.

The timber circle (Fig. 1) was dated by taking six samples (four from the ring of posts and duplicate samples from the central tree) for dendrochronological analysis ${ }^{2}$. The ring sequence from the central stump and the four ring sequences from the posts crossmatched and were combined to form a 168-year site chronology.

This tree-ring sequence was compared with a series of reference chronologies. The highest, but statistically non-significant, correlation was against the East Anglia chronology $^{3}(t=3.98$; higher $t$-values are more significant $\left.{ }^{4}\right)$, giving an end date for the site chronology of $2050 \mathrm{BC}$. It also produced lower correlations against East Anglia ending at $2454 \mathrm{BC}(t=3.17)$ and 2019 BC $(t=3.14)$. Running the ring pattern against the Irish master ${ }^{5}$ gave correlations of $t=3.39$ at $2050 \mathrm{BC}$, but only $t=0.96$ at $2454 \mathrm{BC}$ and $t=1.7$ at $2019 \mathrm{BC}$. Thus, although not statistically significant, dendrochronology suggested that $2050 \mathrm{BC}$ is the most likely end date for the site chronology. However, although the consistency of the $t$-values was encouraging, the correlation values were too low for definitive dating.

Figure 2 Probability distributions of dates from the central tree bole at Holme-next-theSea. Each distribution represents the relative probability that an event occurs at a particular time. For each radiocarbon date, two distributions have been plotted: one in outline (the result of simple radiocarbon calibration), and a solid one (based on the chronological model used). The agreement indices ${ }^{7}$ (A) provide a measure of how well the radiocarbon measurements agree with the absolute date suggested by dendrochronology. The large square bracket on the left and the OxCal keywords define the overall model exactly.

Figure 1 The timber circle at Holme-next-the-Sea in Norfolk, England.
For this reason, six contiguous samples of 20 years' growth from the central tree were submitted for high-precision radiocarbon dating. Incorporating the known chronological separation between the samples and the radiocarbon results in a bayesian model (Fig. 2), each of the possible dates suggested by the tree-ring correlations was tested by using the current calibration curve ${ }^{6}$ and OxCal version 2.18 (ref. 7). The hypothesis that the final ring of the tree-ring chronology dates to $2050 \mathrm{BC}$ is consistent with the radiocarbon results ( $A=27.7 \%$; Fig. 2). However, the radiocarbon evidence is in significant disagreement with the idea that the last ring of the chronology falls in $2454 \mathrm{BC}(A=0.0 \%)$ or 2019 BC $(A=7.6 \%)$.

Radiocarbon calibration has undergone a series of refinements in recent years. Calculating this model using other calibration curves shows that the best agreement is produced by using the 1986 calibration curve ${ }^{8}$

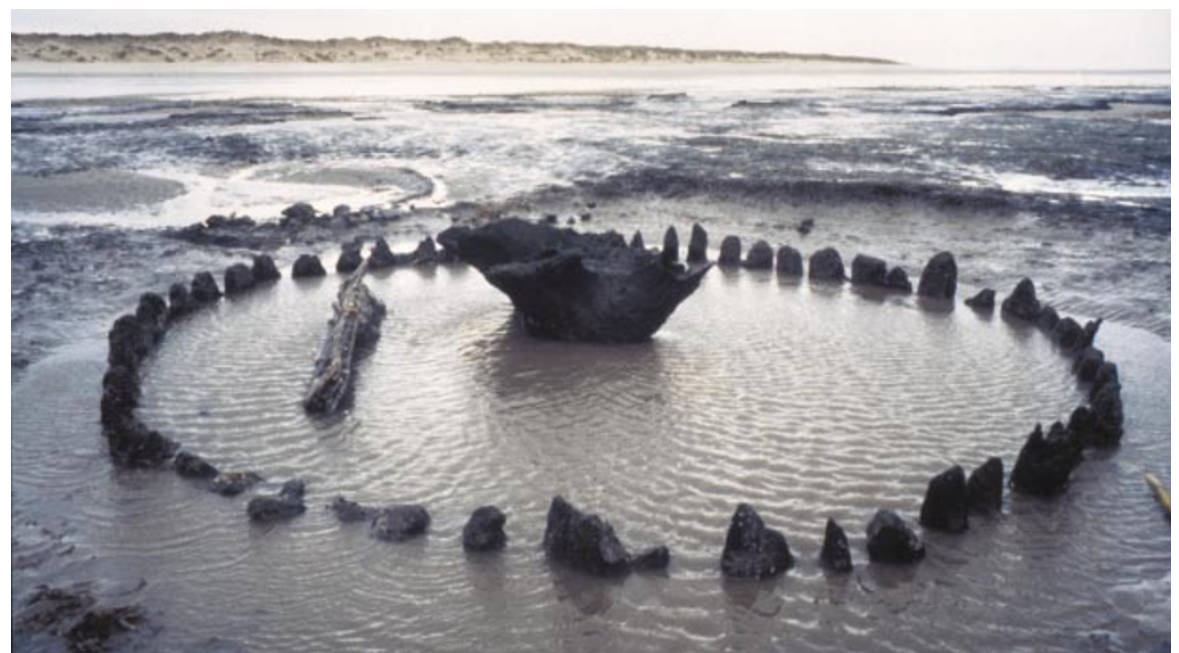

( $A=46.2 \%)$, which indicates that interlaboratory offsets, errors and regional variation in the radiocarbon content of the atmosphere may be significant when producing precise archaeological chronologies 9 .

Combining the information from both dating techniques, including unmeasured partial rings on the outside of the tree-ring samples, reveals that the upturned tree in the centre of the monument died, or was felled, in April to June 2050 BC. The surrounding posts were felled in April to June of the following year, 2049 BC.

Alex Bayliss ${ }^{\star}$, Cathy Groves $\dagger$,

Gerry McCormac $\ddagger$, Mike Baillie $\neq$,

Dave Brown $\ddagger$, Mark Brennand\$

*Ancient Monuments Laboratory,

English Heritage, 23 Savile Row,

London W1X 1AB, UK

$\dagger$ Dendrochronology Laboratory,

Archaeology Research School,

University of Sheffield, Sheffield S1 4DN, UK

$\ddagger$ School of Archaeology and Palaeoecology, Queen's University, Belfast BT7 1NN, UK

$\$ N$ Norfolk Archaeological Unit,

Garsett House, St Andrew's Hall Plain,

Norwich NR3 1AU, UK

e-mail: alex.bayliss@english-heritage.org.uk

1. Buck, C. E., Cavanagh, W. G. \& Litton, C. D. Bayesian Approach to Interpreting Archaeological Data (Wiley, Chichester, 1996).

2. English Heritage Dendrochronology: Guidelines on Producing and Interpreting Dendrochronological Dates (English Heritage, London, 1998).

3. Baillie, M. G. L. \& Brown, D. M. Br. Archaeol. Rep. 196, 543-548 (1988).

4. Baillie, M. G. L. Tree-ring Dating and Archaeology 82-85 (Croom Helm, London, 1982).

5. Pilcher, J. R., Baillie, M. G. L., Schmidt, B. \& Becker, B. Nature 312, 150-152 (1984)

6. Stuiver, M. et al. Radiocarbon 40, 1041-1083 (1998).

7. Bronk Ramsey, C. Radiocarbon 37, 425-430 (1995).

8. Pearson, G. W. \& Stuiver, M. Radiocarbon 28, 839-862 (1986).

9. McCormac, F. G., Baillie, M. G. L., Pilcher, J. R. \& Kalin, R. M. Radiocarbon 37, 395-407 (1995). 